\title{
ANALISIS STRATEGI PENGEMBANGAN KAWASAN WISATA CURUG MUNDING KECAMATAN GUNUNGKENCANA KABUPATEN LEBAK PROVINSI BANTEN
}

\author{
Oleh
}

\author{
Mu'tamirudin \\ Institut Pemerintahan Dalam Negeri \\ mutamirudin@gmail.com
}

\begin{abstract}
$T$ burism is a great potential to increase economic and welfare for the government and the community, therefore it will be very interesting for tourism to become an object of research. In this case the researchers conducted research with the title analysis of the development strategy of the Curug Munding tourism area of Gunungkencana District, Lebak Regency, Banten Province. This study seeks to determine the current problem of Curug Munding tourism conditions, how the development strategy of Curug Munding tourism area and how the expected Curug Munding tourism conditions. To get the results of the above questions, researchers used a qualitative research method with a descriptive approach using data from books on tourism and corroborated by the results of interviews with people who were directly involved with the tourism object of the research object. The analysis used in this study uses a SWOT analysis. The conclusion of the study of Curug Munding tourism conditions currently still has a lack of tourism facilities, then the most appropriate development strategy of the Curug Munding Tourism today is to use the " $W$ O" (Weakness-Opportunity) Strategy, namely by overcoming weaknesses to seize opportunities, Curug Munding tourism conditions is expected to be ready to be promoted as a leading tourist in Lebak Regency, Banten. This can be realized if all weaknesses can be overcome, especially tourist facilities, especially the location of the entrance.
\end{abstract}

Keywords: Curug Munding, tourism, SWOT analysis

\begin{abstract}
AbStrak
$\mathrm{P}$ ariwisata merupakan potensi yang besar untuk meningkatkan perekonomian dan kesejahteraan bagi pemerintah maupun masyarakat oleh sebab itu akan sangat menarik masalah pariwisata untuk jadi objek penelitian. Dalam hal ini peneliti mengadakan penelitian dengan judul analisis strategi pengembangan Kawasan wisata Curug Munding Kecamatan Gunungkencana Kabupaten Lebak, Provinsi Banten. Penelitian ini berusaha untuk mengetahui masalah kondisi wisata Curug Munding saat ini, bagaimana strategi pengembangan kawasan wisata Curug Munding dan bagaimana kondisi wisata Curug Munding yang diharapkan. Untuk mendapatkan hasil dari pertanyaan di atas, peneliti menggunakan metode penelitian kualitatif dengan pendekatan deskriptif dengan menggunakan data dari buku-buku tentang pariwisata dan dikuatkan dengan hasil wawancara kepada orang-orang yang terlibat langsung dengan objek wisata yang menjadi objek penelitian. Analisis yang dipakai dalam penelitian ini menggunakan Analisis SWOT. Simpulan dari penelitian kondisi wisata Curug Munding saat ini masih memiliki kekurangan fasilitas wisata, kemudian strategi pengembangan Wisata
\end{abstract}


Curug Munding yang paling tepat saat ini adalah menggunakan Strategi "W-O" (WeaknessOpportunity), yaitu dengan mengatasi kelemahan untuk merebut peluang, Kondisi wisata Curug Munding yang diharapkan siap dipromosikan sebagai wisata unggulan di Kabupaten Lebak, Banten. Hal ini bisa terwujud apabila semua kelemahan bisa diatasi, terutama fasilitas wisata khususnya jalan masuk lokasi.

Kata kunci: Curug Munding, pariwisata dan Analisis SWOT

\section{PENDAHULUAN}

aatini pariwisata telah menjadi salah satu - primadona bagi negara-negara dalam meningkatkan sumber pendapatannya. Indonesia sebagai salah satu negara berkembang mulai mempromosikan negaranya guna menarik pandangan mata dunia lain. Hal ini dimaksudkan agar Indonesia semakin terkenal bagi warga negara lain untuk berkunjung ke Indonesia. Promosi-promosi yang saat ini kerap dilakukan adalah untuk menjual keragaman wisata dan budaya Indonesia, hal ini ditanggapi positif dengan banyaknya wisatawan mancanegara yang berkunjung ke Indonesia.

Demikian pula seharusnya dilakukan di setiap wilayah termasuk di Kabupaten Lebak Banten dan harapan itu dapat terlaksana karena Desa Cicaringin Kecamatan Gunungkencana memiliki sumber daya alam yang potensial untuk dikembangkan menjadi objek wisata unggulan, yaitu air terjun "Curug Munding". Salah satu destinasi wisata yang memiliki potensi wisata dan diminati oleh pengunjung adalah wisata alam yang menjanjikan keindahan bagi para pengunjungnya. Seperti halnya objek wisata Curug Munding yang merupakan salah satu wisata alam yang terletak di Desa Cicaringin, Kecamatan Gunungkencana Kabupaten Lebak, Provinsi Banten. Curug atau air terjun ini memiliki curahan air terjun yang lebar dengan lokasi yang relatif dekat dengan perkampungan penduduk dan persawahan yang asri. Destinasi wisata ini berjarak sekitar 58 kilometer dari pusat Kabupaten Lebak, Rangkasbitung, dan sekitar 133 kilometer dari Jakarta. Saat ini Curug Munding dikelola oleh Badan Usaha Milik Desa Cicaringin, Kecamatan Gunungkencana Kabupaten Lebak. Keindahan air terjun tersebut diyakini akan menarik wisatawan dari berbagai daerah, baik dari Banten, nasional maupun internasional. Kepala Bidang Pemasaran Dinas Pariwisata Kabupaten Lebak, Oktavianto Arief mengatakan:

Curug Munding merupakan objek wisata yang indah dan menarik. Karenanya, Dinas Pariwisata Lebak akan menjadikan tempat itu sebagai destinasi wisata unggulan, bersama Baduy dan Pantai Sawarna. Dari puluhan tempat wisata yang ada, kita punya tiga destinasi wisata unggulan, yakni Curug Munding, Pantai Sawarna, dan Baduy (Oktavianto Arief, Radar Banten, 2018).

Menurut Soekadijo (1995), industri pariwisata akan memberikan dampak positif bagi pemerintah dan masyarakat tempat beradanya pariwisata. Ini berarti keadaan pariwisata sendiri sangat penting dalam meningkatkan taraf hidup masyarakat sekitarnya. Angka kemiskinan yang ada di Kecamatan Gunungkencana, Lebak, Banten masih cukup tinggi. Berkembangnya kegiatan pariwisata di daerah Curug Munding diharapkan akan memberikan pengaruh yang besar, baik terhadap kondisi lingkungan fisik, kebersihan, keindahan, ekonomi, sosial, budaya, serta pertahanan dan keamanan bagi masyarakat, khususnya penduduk Desa Cicaringin, Kecamatan Gunungkencana dan Kabupaten Lebak, Banten. Dampak positif terhadap bidang ekonomi dari berkembangnya kawasan wisata ini, yaitu menciptakan lapangan pekerjaan (kesempatan usaha) yang cukup luas bagi penduduk Kecamatan 
Gunungkencana. Peluang tersebut antara lain bekerja sebagai petugas parkir, petugas kebersihan, pedagang, kesenian, sovenir berupa kerajinan tangan, usaha jasa angkutan dan lain-lain yang tentunya akan menekan angka kemiskinan masyarakat.

\section{TINJAUAN PUSTAKA}

\section{Pariwisata}

Pariwisata dapat dipergunakan sebagai katalisator dari kegiatan pembangunan. Kepariwisataan merupakan mata rantai panjang yang dapat menggerakkan bermacam-macam kegiatan dalam kehidupan masyarakat. Sebelum membahas lebih lanjut, kita harus mengetahui pengertian dari pariwisata.

Menurut Sinaga (2010), pariwisata merupakan suatu perjalanan yang terencana, yang dilakukan secara individu maupun kelompok dari satu tempat ke tempat lain dengan tujuan untuk mendapatkan suatu bentuk kepuasan dan kesenangan semata. Adapun menurut Undang-Undang No. 10 Tahun 2009 Pasal 1 ayat (3), menyebutkan bahwa pariwisata adalah berbagai macam kegiatan pariwisata dan didukung oleh berbagai fasilitas serta layanan yang disediakan oleh masyarakat, pengusaha, pemerintah dan pemerintah daerah. Ada juga pendapat WTO (World Tourism Organization), pariwisata merupakan aktivitas manusia yang melaksanakan perjalanan dan tinggal di daerah tujuan perjalanan di luar lingkungan/daerah kesehariannya. Dan pendapat terakhir menurutSalahWahab, pariwisatamerupakan aktivitas manusia yang dikerjakan secara sadar, yang mendapat pelayanan secara bergantian di antara orang-orang di dalam suatu negara itu sendiri ataupun di luar negeri untuk mendapatkan kepuasan yang beraneka ragam dan berbeda antara satu orang dengan orang lainnya.

Berdasarkan beberapa definisi di atas, dapat disimpulkan bahwa pariwisata merupakan suatu kegiatan untuk mendapatkan kepuasan dengan cara melaksanakan perjalanan dan mendapatkan fasilitas layanan yang disediakan oleh masyarakat, pengusaha, pemerintah dan pemerintah daerah.

\section{Strategi}

Menurut Stanton (dalam Amirullah, 2004: 4) strategi sebagai suatu rencana dasar yang luas dari suatu tindakan organisasi untuk mencapai suatu tujuan. Rencana dalam mencapai tujuan tersebut sesuai dengan lingkungan eksternal dan internal perusahaan.

Sementara itu, Christensen dalam Rangkuti (2005: 3) mengungkapkan bahwa strategi merupakan alat untuk mencapai keunggulan bersaing. Porter dalam Rangkuti (2005: 4) mengungkapkan bahwa strategi adalah alat yang sangat penting untuk mencapai keunggulan bersaing.

Menurut Chandler dalam Rangkuti (2005: 3) strategi merupakan alat untuk mencapai tujuan perusahaan dalam kaitannya dengan tujuan jangka panjang, program tindak lanjut serta prioritas alokasi sumber daya. Dalam Kamus Besar Bahasa Indonesia, strategi adalah ilmu dan seni menggunakan semua sumber daya bangsabangsa untuk melaksanakan kebijakan tertentu di perang dan damai, atau rencana yang cermat mengenai kegiatan untuk mencapai sasaran khusus.

Dari beberapa tinjauan di atas, maka dapat dicapai sebuah pengertian tentang strategi yang akan dipakai dalam penelitian ini, yaitu suatu kesatuan rencana dalam bentuk program-program yang terpadu dan menyeluruh untuk mencapai keunggulan bersaing dalam mencapai tujuan. Menurut Anshori (2014; 18-20) untuk menentukan atau membuat strategi ada tiga tahap proses strategi berikut. 
1) Perumusan strategi.

Tahapan ini berupa tahap untuk mengembangkan visi dan misi, mengidentifikasi peluang dan ancaman eksternal, menentukan kekuatan dan kelemahan internal, menetapkan tujuan jangka panjang, membuat sejumlah strategi alternatif, dan memilih strategi tertentu.

\section{2) Pelaksanaan strategi}

Tahap ini mengharuskan sebuah instansi untuk menetapkan sasaran tahunan, membuat kebijakan, memotivasi anggota, dan mengalokasi sumber daya sehingga perumusan strategi dapat dilaksanakan.

\section{3) Evaluasi strategi}

Pada tahap ini, pimpinan harus benar-benar mengetahui alasan strategi-strategi tertentu tidak dapat dilaksanakan dengan baik. Dalam hal ini, evaluasi strategi adalah cara pertama untuk memperoleh informasi. Semua strategi dapat berubah sewaktu-waktu karena faktor eksternal dan internal selalu berubah.

\section{Pengembangan Pariwisata}

Menurut Kamus Besar Bahasa Indonesia (2007: 538) pengembangan adalah proses, cara, perbuatan mengembangkan. Ditambahkan oleh Poerwa Darminto (2002: 474) pengembangan adalah suatu proses atau cara menjadikan sesuatu menjadi maju, baik, sempurna, dan berguna. Pengembangan dalam penelitian ini diartikan sebagai proses atau perbuatan pengembangan dari belum ada, dari yang sudah ada menjadi lebih baik dan dari yang sudah baik menjadi lebih baik, demikian seterusnya.

Pengembangan pariwisata adalah suatu usaha untuk mengembangkan atau memajukan objek wisata agar objek wisata tersebut lebih baik dan lebih menarik ditinjau dari segi tempat maupun benda-benda yang ada di dalamnya untuk dapat menarik minat wisatawan untuk mengunjunginya.

Pengembangan pariwisata sebagai suatu industri secara ideal harus berlandaskan pada empat prinsip dasar, sebagaimana dikemukakan Sobari (Anindita, 2015), berikut ini.

1) Kelangsungan ekologi, yaitu bahwa pengembangan pariwisata harus menjamin terciptanya pemeliharaan dan proteksi terhadap sumber daya alam yang menjadi daya tarik pariwisata, seperti lingkungan laut, hutan, pantai, danau, dan sungai.

2) Kelangsungan kehidupan sosial dan budaya, yaitu bahwa pengembangan pariwisata harus mampu meningkatkan peran masyarakat dalam pengawasan tata kehidupan melalui sistem nilai yang dianut masyarakat setempat sebagai identitas masyarakat tersebut.

3) Kelangsungan ekonomi, yaitu bahwa pengembangan pariwisata harus dapat menciptakan kesempatan kerja bagi semua pihak untuk terlibat dalam aktivitas ekonomi melalui suatu sistem ekonomi yang sehat dan kompetitif.

4) Memperbaiki dan meningkatkan kualitas hidup masyarakat setempat melalui pemberian kesempatan kepada mereka untuk terlibat dalam pengembangan pariwisata.

Pengembangan potensi daya tarik atau atraksi wisata meliputi daya tarik alami yang bersifat melekat (inherent) dengan keberadaan objek wisata alam tersebut. Selain daya tarik alami, suatu objek wisata memiliki daya tarik buatan manusia (man made attraction). Menurut Santoso dalam Kurniawan (2015) unsur-unsur pengembangan pariwisata, meliputi:

1) Atraksi atau daya tarik dapat timbul dari keadaan alam (keindahan panorama, flora dan fauna, sifat khas perairan laut, danau), objek buatan manusia (museum, 
katedral, masjid kuno, makam kuno dan sebagainya), ataupun unsur-unsur dan peristiwa budaya (kesenian, adat istiadat, makanan dan sebagainya).

2) Transportasi

Perkembangan transportasi berpengaruh atas arus wisatawan dan juga perkembangan akomodasi. di samping itu perkembangan teknologi transportasi juga berpengaruh atas fleksibilitas arah perjalanan, Jika angkutan dengan kereta api bersifat linier, tidak banyak cabang atau kelokannya, dengan kendaraan mobil arah perjalanan dapat menjadi lebih bervariasi. Demikian pula dengan angkutan pesawat terbang yang dapat melintasi berbagai rintangan alam (waktu yang lebih singkat).

3) Akomodasi

Tempat menginap dapat dibedakan antara yang dibangun untuk keperluan umum (hotel, motel, tempat pondokan, tempat berkemah waktu liburan) dan yang diadakan khusus perorangan untuk menampung menginap keluarga, kenalan atau anggota perkumpulan tertentu atau terbatas.

4) Fasilitas pelayanan penyediaan

Fasilitas dan pelayanan makin berkembang dan bervariasi sejalan dengan perkembangan arus wisatawan. Perkembangan pertokoan dan jasa pelayanan di tempat wisata dimulai dengan adanya pelayanan jasa kebutuhan sehari-hari (penjual makanan, warung minum atau jajanan), kemudian jasa-jasa perdagangan (pramuniaga, tukang-tukang atau jasa pelayanan lain), selanjutnya jasa untuk kenyamanan dan kesenangan (toko pakaian, toko perabot rumah tangga, dll), lalu jasa yang menyangkut keamanan dan keselamatan (dokter, apotek, polisi dan pemadam kebakaran), dan pada akhirnya perkembangan lebih lanjut menyangkut juga jasa penjualan barang mewah.

5) Infrastruktur yang memadai diperlukan untuk mendukung jasa pelayanan dan fasilitas pendukung. Pembangunan infrastruktur secara tidak langsung juga memberi manfaat (dapat digunakan) bagi penduduk setempat di samping mendukung pengembangan pariwisata. Hal ini menyangkut tidak saja pembangunan infrastruktur transportasi (jalan, pelabuhan, jalan kereta api, dll), tetapi juga penyediaan saluran air minum, penerangan listrik, dan juga saluran pembuangan limbah.

Di samping itu pengembangan pariwisata bertujuan untuk memberikan keuntungan bagi wisatawan maupun komunitas tuan rumah. Dengan adanya pembangunan pariwisata diharapkan mampu meningkatkan taraf hidup masyarakat melalui keuntungan secara ekonomi yang dibawa ke kawasan tersebut. Dengan kata lain pengembangan pariwisata melalui penyediaan fasilitas infrastruktur, wisatawan dan penduduk setempat akan saling diuntungkan. Pengembangan tersebut hendaknya sangat memperhatikan berbagai aspek, seperti; aspek budaya, sejarah dan ekonomi daerah tujuan wisata. Pada dasarnya pengembangan pariwisata dilakukan untuk memaksimalkan keuntungan dan meminimalkan permasalahan (Mill, 2000: 168).

Pengembangan pariwisata secara mendasar memperhatikan beberapa konsep seperti: 1) Pengembangan Pariwisata Berkelanjutan, 2) Pembangunan Wilayah Terpadu dan Pengembangan Produk Wisata; 3) Pembangunan Ekonomi Pariwisata; serta 4) Pengembangan Lingkungan.

\section{Batasan Masalah}

Dalam pengkajian ini mengangkat permasalahan mengenai analisis strategi pengembangan kawasan wisata. Agar 
pengkajian tidak meluas dibatasi masalah pada analisis terhadap langkah nyata yang perlu dilakukan untuk Pengembangan Kawasan Wisata Curug Munding, Kecamatan Gunungkencana, Kabupaten Lebak, Banten.

\section{Rumusan Masalah}

Berdasarkan latar belakang masalah yang telah diuraikan dalam penelitian dapat dinyatakan bahwa rumusan masalahnya, yaitu:

a. Bagaimana kondisi wisata Curug Munding saat ini?

b. Bagaimana strategi pengembangan kawasan wisata Curug Munding?

c. Bagaimana kondisi wisata Curug Munding yang diharapkan?

\section{Tujuan Penelitian}

1) Menjadikan objek wisata Curug Munding sebagai destinasi wisata unggulan di Kabupaten Lebak.

2) Meningkatkan kesejahteraan masyarakat dan pendapatan asli daerah.

3) Untuk meningkatkan stabilitas pertahanan dan keamanan melalui ekonomi kerakyatan, mengatasi pengangguran, serta menciptakan kesejahteraan masyarakat Kecamatan Gunungkencana dan Kabupaten Lebak

\section{METODE PENELITIAN}

Metode yang digunakan adalah metode kualitatif dengan pendekatan deskriptif. Penelitian yang menggunakan pendekatan kualitatif bertujuan untuk menggali atau membangun suatu proposisi atau menjelaskan di balik realita. Penelitian kualitatif bertujuan untuk mendapatkan pemahaman yang sifatnya umum terhadap kenyataan sosial dari perspektif partisipan (Basrowi \& Suwandi, 2008: 23). Melalui analisis deskriptif penulis berusaha untuk mendapatkan gambaran keadaan yang sedang berlangsung terhadap objek penelitian. Dalam penelitian kualitatif membutuhkan data yang pasti. Data yang sebenarnya telah terjadi dan bukan merupakan sebuah manipulasi. Digunakan untuk mendapatkan data yang mendalam, suatu data yang mengandung makna, makna di balik data yang sebenarnya. Data tersebut berupa fakta dan pemahaman yang bersifat umum dan diperoleh dari berbagai sumber baik dari wawancara berdasarkan pengalaman, studi Pustaka maupun dari berita-berita aktual yang ada.

\section{Teknik Analisis Data}

Dalam pengkajian ini menggunakan teknik analisis SWOT (strengths, weaknesses, opportunities, dan threats). Langkah awal peneliti mengumpulkan data dari berbagai sumber yang didapat, berdasarkan datadata tersebut maka dapat diketahui faktafakta yang ada di lapangan, dan berdasarkan fakta-fakta yang telah ditemukan tersebut tim pengkaji menganalisis dengan metode SWOT. Analisis SWOT adalah suatu metode analisis yang digunakan untuk menentukan dan mengevaluasi, mengklarifikasi dan memvalidasi perencanaan yang telah disusun, sesuai dengan tujuan yang ingin dicapai. Analisis ini merupakan suatu metode untuk menggali aspek-aspek kondisi yang terdapat di suatu wilayah yang direncanakan maupun untuk menguraikan berbagai potensi dan tantangan yang akan dihadapi dalam pengembangan wilayah tersebut. Kata SWOT itu sendiri merupakan kependekan dari variabel-variabel penilaian, yaitu:

a. Strengths (S) yang berarti potensi dan kekuatan yang terdapat dalam tubuh organisasi.

b. Weaknesses (W) yang berarti masalah dan tantangan di dalam organisasi yang dihadapi.

c. Opportunities (O) yang berarti peluang merupakan kondisi peluang berkembang di masa datang yang terjadi. Kondisi yang terjadi merupakan 
peluang dari luar organisasi, misalnya kompetitor, kebijakan pemerintah, kondisi lingkungan sekitar.

d. Threats (T) yang merupakan faktor eksternal yang berpengaruh dalam pembangunan, merupakan kondisi yang mengancam dari luar. Ancaman ini dapat mengganggu organisasi.

Analisis SWOT bertujuan untuk mengidentifikasi berbagai faktor secara sistematis untuk merumuskan suatu strategi. Sebagai sebuah konsep dalam manajemen strategis, teknik ini menekankan mengenai perlunya penilaian lingkungan eksternal dan internal, serta kecenderungan perkembangan/perubahan di masa depan sebelum menetapkan sebuah strategi. Analisis ini didasarkan pada logika yang dapat memaksimalkan kekuatan (strengths) dan peluang (opportunities), namun secara bersamaan dapat meminimalkan kelemahan (weaknesses) dan ancaman (threats).

\section{HASIL DAN PEMBAHASAN}

\section{Kondisi Wisata Curug Munding}

\section{- Potensi}

Daerah tujuan wisata merupakan salah satu komponen penting sumber daya pariwisata. Faktor geografi merupakan faktor penting untuk pertimbangan pengembangan kepariwisataan. Pendekatan geografi yang mendasarkan pada dua aspek keruangan mempunyai kaitan yang erat dengan persebaran dari suatu objek pembahasan. Pengembangan pariwisata yang menggunakan pendekatan keruangan dapat dilihat dari kedudukan objek wisata terhadap objek wisata yang lain, hal ini dimaksudkan untuk melihat potensi yang dimiliki objek wisata dan adanya kemungkinan untuk dikembangkan atau berkembang (Sujali, 1989). Posisi Wisata Curug Munding berjauhan dengan wisata lain yang ada di Kabupaten Lebak, misalnya; Pantai Sawarna dan Pantai Bagedur.
Berdasarkan hasil observasi tim pengkaji pada Jumat, 13 April 2018 dan Minggu, 15 April 2018 di kawasan wisata Curug Munding, kawasan wisata ini memiliki keindahan alam yang masih alami dan masih jarang dijamah oleh masyarakat. Jika dibandingkan dengan tempat wisata sejenisnya, Curug Munding dianggap sebagai air terjun yang sangat indah karena keadaan air terjunnya yang lebih lebar dari air terjun yang ada biasanya, yaitu kurang lebih selebar lima meter. Seperti yang diungkapkan oleh Hendro, salah satu pengunjung yang berkunjung ke kawasan wisata Curug Munding pada Minggu, 15 April 2018 yang mengatakan:

"Air terjun di sini sangat menarik, lebih besar dibandingkan dengan air terjun lainnya dengan pemandangan yang lebih cantik dan alami."

Pernyataan oleh Hendro tersebut juga didukung oleh pendapat Andi yang mengatakan bahwa:

"Air terjunnya lebih luas dibandingkan dengan air terjun yang saya kunjungi sebelumnya di tempat lain."

\section{- Fasilitas}

\section{- Jalan}

Fasilitas jalan menuju lokasi Curug Munding masih kurang memadai. Kondisi jalannya rusak membuat kendaraan sulit lewat dan berbahaya bagi keselamatan pengendara sepeda motor. Hal ini didukung oleh hasil wawancara tim dengan pengunjung Andi yang mengatakan bahwa:

"Kondisi jalan menuju tempat ini yang sangat jauh, sempit, rusak, berbatu dan sangat sulit untuk dilalui."

Kondisi jalan juga sempit sehingga kendaraan roda empat sulit untuk dilewati bahkan kendaraan besar seperti bus tidak bisa melewati. Kondisi akses jalan yang demikian tersebut membuat minat pengunjung untuk berwisata ke Curug Munding berkurang. Selain itu, di sepanjang 
jalan menuju Curug Munding belum ada petunjuk jalan yang dapat memudahkan pengunjung menemukan lokasi Curug Munding sehingga banyak pengunjung yang merasa kebingungan untuk menemukannya.

\section{- Parkir}

Belum adanya lahan parkir yang cukup untuk menampung pengunjung dalam jumlah besar. Seperti yang dikatakan Andi sebagai salah satu pengunjung bahwa:

"Perlu dilaksanakan pembangunan infrastruktur jalan dari tempat parkir menuju tempat wisata, jembatan di atas aliran curug agar menambah nilai pariwisata pengunjung. Selama ini tempat parkir yang ada menggunakan pekarangan rumah warga sekitar yang luasnya tidak seberapa sebagai lahan parkir tidak akan cukup menampung kendaraan dalam jumlah besar.

Sama halnya seperti yang disampaikan oleh Asep sebagai Ketua Pokdarwis bahwa:

"Tidak ada petugas parkir secara resmi, petugas parkir berasal dari warga sekitar yang halaman rumahnya dijadikan lahan parkir."

\section{- Kamar Ganti dan WC}

Berdasarkan observasi tim pengkaji, kondisi kamar ganti dan WC yang ada masih belum memadai sehingga masih diperlukan renovasi/perbaikan. Kondisi WC tidak ada air dan ruangan terlalu sempit serta jumlahnya terlalu sedikit. Selain itu letak WC yang kurang tepat, yaitu terletak di samping warung makan. Hal tersebut membuat pengunjung kurang nyaman.

\section{- Kantin}

Kantin yang ada di lokasi wisata Curug Munding saat ini masih kurang memadai dan bersifat darurat. Makanan yang dijual kurang bervariasi dan kondisinya kurang menarik, hal ini disebabkan karena jumlah pengunjung yang masih terbatas dan hanya pada saat hari libur saja. Lokasi kantin kurang strategis sehingga pengunjung tidak dapat menikmati indahnya pemandangan air terjun.

\section{- Gazebo dan Tempat Duduk}

Para pengunjung yang kelelahan memerlukan tempat duduk atau tempat istirahat sejenak sambil menikmati kesejukan dan keindahan alam. Tempat duduk yang ada masih kurang memadai, yaitu hanya berupa bambu dan kayu dari pohon yang sudah tumbang.

\section{- Musala}

Di kawasan Curug Munding tersedia musala namun masih dengan kondisi darurat.

\section{- Kebersihan dan Keindahan}

Berdasarkan observasi kawasan wisata Curug Munding masih memiliki beberapa kekurangan di bidang kebersihan, yaitu belum adanya petugas kebersihan dan kurangnya tempat sampah di lokasi wisata sehingga membuat kondisi kotor dan banyak sampah yang berserakan. Selain itu, masih kurang sesuainya penataan tempat dan belum adanya taman.

\section{- Keamanan}

Belum adanya petugas keamanan yang berjaga di kawasan wisata Curug Munding, sehingga masyarakat merasa kurang aman karena tidak ada yang mengawasi atau tidak ada yang memperingatkan pengunjung bila ada keadaan bahaya di sekitar kawasan wisata Curug Munding.

\section{- Promosi}

Tidakada promosi dari pihak pemerintah maupun pengelola wisata tersebut, selama ini hanya dilakukan berdasarkan informasi dari pengunjung. Berdasarkan hasil wawancara dengan Kepala Desa Cicaringin, H. Nana Sukroadi: 
"Selama ini belum pernah ada promosi karena menurut saya kondisi Curug Munding sendiri yang belum layak untuk dipromosikan sebagai destinasi wisata."

Berdasarkan ungkapan Kepala Desa tersebut bahwa sampai saat ini kawasan wisata Curug Munding belum dipromosikan dengan baik karena fasilitas wisata sendiri yang belum memenuhi standar sebagai tempat wisata yang baik.

\section{- Manajemen Pengelolaan}

Selama ini manajemen pengelolaan yang dilakukan belum berjalan dengan baik hal ini kemungkinan disebabkan karena kondisi wisata Curug Munding yang belum optimal untuk dioperasionalkan. Berdasarkan hasil wawancara dengan Ketua Kesadaran Wisata Curug Munding Desa Cicaringin, Asep bahwa:

"Belum ada sistem pengelolaan wisata Curug Munding yang jelas dan profesional."

Dengan sistem pengelolaan yang baik mulai dari perencanaan, pengorganisasian, pelaksanaan dan pengawasan tentunya akan dengan mudah untuk meraih keberhasilan khususnya Wisata Curug Munding. Dengan pengelolaan yang profesional diharapkan wisata akan dapat menghasilkan income yang lebih besar dibanding apabila tidak terkelola dengan baik.

\section{- Kondisi Masyarakat Sekitar}

Kondisi masyarakat di sekitar kawasan wisata Curug Munding pada umumnya berada di bawah garis kemiskinan, dapat dilihat dari penduduk yang kebanyakan hanya bermata pencaharian sebagai petani karet maupun padi serabutan, kondisi rumah dengan lantai tanah dan dinding anyaman bambu. Bahkan banyak masyarakat yang melaksanakan urbanisasi untuk mencari pekerjaan.

Berdasarkan hasil wawancara dengan Kepala Desa Cicaringin, yang mengatakan bahwa:

\begin{abstract}
"Seluruh masyarakat desa Cicaringin sangat mendukung apabila objek wisata Curug Munding dikembangkan menjadi wisata unggulan. Karena akan berpengaruh kepada penyerapan tenaga kerja sehingga diharapkan masyarakat dengan mudah mendapatkan pekerjaan."
\end{abstract}

Kondisi tersebut hanya dapat terwujud apabila terjadi perubahan dan pengembangan kawasan wisata Curug Munding tersebut. Curug Munding apabila dikembangkan sedemikian rupa tentunya akan meningkatkan kesejahteraan ekonomi dan pembangunan masyarakat sekitar.

\section{- Area Sekitar Lokasi}

Berdasarkan hasil observasi banyak infrastruktur yang belum memadai, di antaranya: 1) Belum ada jembatan menuju jalan setapak ke lokasi; 2) Jalan setapak sudah dibangun dengan paving block, namun masih melewati pematang sawah yang becek; 3) Tangga menuju lokasi Curug Munding licin dan sempit; 4) Lantai lokasi masih berupa tanah, sehingga selalu terkesan kotor; 5) Dinding tepi sungai masih berupa tanah yang rawan longsor dan terkesan kotor; 6) Area untuk menikmati pemandangan air terjun kurang luas dan kurang tempat duduk. 7) Posisi kantin berdampingan dengan kamar ganti dan WC; 8) Belum tersedianya air bersih di WC dan belum ada listrik.

\section{Strategi Pengembangan Kawasan Wisata Curug Munding}

Untuk dapat mencapai tujuan dan sasaran penulis melakukan identifikasi dan menganalisis faktor lingkungan dengan menggunakan analisis SWOT. Faktor-faktor yang memengaruhi adalah faktor internal, yaitu kekuatan (strengths) dan kelemahan (weaknesses) maupun faktor eksternal, yaitu peluang (opportunities) dan ancaman (threats). Hasil inventarisir melalui observasi dan wawancara diperoleh faktor-faktor sebagai berikut. 
a. Faktor Internal:

1) Faktor kekuatan (strengths) antara lain: Pemandangan yang indah dan sejuk (green view); Mendapat dukungan masyarakat; Ketersediaan Sumber Daya Manusia.

2) Faktor kelemahan (weaknesses) antara lain: Kurangnya fasilitas wisata (petunjuk gerbang masuk, jalan, tempat parkir, taman, tangga ke lokasi, listrik, tempat duduk, toilet); Kurangnya manajemen dan kesadaran wisata; Kurangnya promosi kepada publik.

b. Faktor Eksternal:

1) Faktor peluang (opportunities) antara lain: Destinasi wisata alam yang digemari; Dukungan Pemerintah dalam sektor pariwisata; Sebagai pasar potensial.

2) Faktor ancaman (threats) antara lain: Pesaing sejenis di kawasan kota lain; Adanya pesaing pariwisata modern; Selera masyarakat yang sering berubah-ubah.

Selanjutnya dengan memperhatikan evaluasi faktor internal dan eksternal, penentuan faktor-faktor kunci keberhasilan seperti termuat dalam lampiran, maka dapat ditentukan peta posisi organisasi.

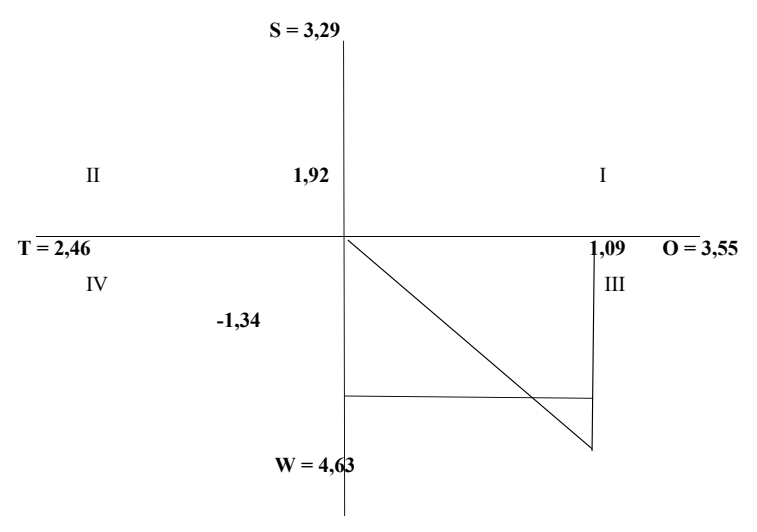

Gambar 1

Peta Posisi Kekuatan Organisasi

Berdasarkan jumlah masing-masing dari strengths, weaknesses, opportunities dan threats dapat dipetakan posisi kekuatan organisasi dengan diagram Cartesius sebagaimana tampak pada Gambar 1 di atas.

Gambar 1 di atas menunjukkan bahwa posisi kekuatan organisasi berada pada kuadran III, artinya strategi yang digunakan adalah strategi "WO" (weaknesses-opportunities), dapat diterjemahkan bahwa diperlukan upaya "mengatasi kelemahan untuk merebut peluang". Adapun strategi "W-O" tersebut adalah mengatasi kelemahan terutama pembangunan jalan beserta fasilitas wisata lainnya untuk meraih peluang, yaitu sebagai pasar potensial.

\section{Kondisi yang Diharapkan}

Menurut Murphy dalam Pitana dan Gayatri (2005), pariwisata adalah keseluruhan dari elemen-elemen terkait (wisatawan, daerah tujuan wisata, perjalanan, industri, dan lain-lain) yang merupakan akibat dari perjalanan wisata ke daerah tujuan wisata, sepanjang perjalanan tersebut dilakukan secara tidak permanen. Selanjutnya pengertian pariwisata jika dilihat dalam Undang-Undang No. 9 Tahun 1990 tentang Kepariwisataan dalam Pasal 1 menyatakan bahwa wisata adalah kegiatan perjalanan atau sebagian dari kegiatan tersebut yang dilakukan secara sukarela serta bersifat sementara untuk menikmati objek dan daya tarik wisata.

Seperti halnya yang diuraikan pada sub bab sebelumnya bahwa strategi yang paling tepat digunakan saat ini adalah strategi "W-O" (Weaknesses-Opportunities), yaitu: "mengatasi kelemahan untuk merebut peluang". Dalam mewujudkan cita-cita berupa Wisata Curug Munding yang siap untuk dipromosikan maka kondisi itulah yang menjadi kondisi yang diharapkan. Untuk lebih jelasnya berikut akan diuraikan secara terperinci kondisi yang diharapkan tersebut. 


\section{Mengatasi Faktor Kelemahan (Weaknesses)}

- Kurangnya Fasilitas Wisata

- Jalan

Darmadjati dalam Ediwarsyah (1987) mengemukakan bahwa: pengertian objek pariwisata adalah pada garis besarnya berwujud objek, barang-barang mati atas statis, baik yang diciptakan oleh manusia sebagai hasil seni budaya, atau yang berupa gejala-gejala alam yang memiliki daya tarik kepada para wisatawan untuk mengunjunginya agar dapat menyaksikan, mengagumi, menikmati sehingga terpenuhi rasa kepuasan wisatawan-wisatawan itu, sesuai dengan motif kunjungannya.

Adapun menurut Undang-Undang No. 9 Tahun 1990, objek pariwisata adalah pewujudan dari ciptaan Tuhan, tata hidup, seni budaya, sejarah bangsa dan tempat serta keadaan alam yang mempunyai daya tarik untuk kunjungan wisata.

Salah satu objek wisata yang memiliki potensi untuk dikembangkan adalah Wisata Air terjun Curug Munding di Lebak Banten. Namun, selama ini masih ada keluhan dari pengunjung, yaitu sulitnya akses menuju objek wisata dan jalan yang kurang nyaman untuk para pengunjung. Oleh karena itu, perlu dilaksanakan perbaikan dan pelebaran jalan menuju kawasan wisata Curug Munding agar pengunjung merasa lebih nyaman dan meningkatkan minat pengunjung untuk berkunjung ke kawasan wisata Curug Munding serta adanya pendukung jalan seperti petunjuk jalan menuju objek wisata dan penerangan lampu pada jalan.

Pembangunan jalan menuju wisata Curug Munding bukan hanya untuk tujuan wisata, namun juga untuk lalu lintas masyarakat yang ada di sekitar lokasi.

\section{- Parkir}

Sarana parkir merupakan salah satu faktor penentu dari minat kunjungan wisata.
Sebaiknya dilaksanakan pembangunan infrastruktur parkir yang cukup luas dan sudah menggunakan paving block. Untuk pengunjung tempat wisata Curug Munding.

Hal tersebut akan meningkatkan kenyamanan dan rasa aman pengunjung.

\section{- Kamar Ganti dan WC}

Kamar ganti dan WC merupakan salah satu fasilitas yang dibutuhkan oleh pengunjung untuk berganti pakaian maupun melakukan pembersihan setelah menikmati dan mengunjungi wisata Curug Munding. Sebaiknya dibuat kamar ganti dan WC dalam jumlah yang memadai, memiliki sanitasi dan aliran air yang baik serta listrik/penerangan.

Selain itu, akan lebih baik kamar ganti dan WC tidak terletak di sekitar warung makan, jadi diperlukan penataan ulang terhadap letak kamar ganti dan WC.

\section{- Kantin}

Kantin merupakan salah satu fasilitas yang membuat pengunjung menjadi nyaman, dapat memenuhi kebutuhannya seperti minum, makanan ringan dan sebagainya. di samping untuk pengunjung kantin juga bermanfaat bagi pedagang sebagai sumber penghasilan.

Kantin yang ada di kawasan wisata Curug Munding akan lebih baik bila dibangun dengan bangunan yang permanen dan menyediakan makanan yang bervariasi agar pengunjung lebih nyaman.

\section{- Gazebo dan Tempat Duduk}

Sebaiknya dibangun gazebo yang menarik dan tempat duduk yang permanen dalam jumlah yang memadai, sehingga dapat dimanfaatkan pengunjung sebagai tempat untuk beristirahat.

\section{- Musala}

Fasilitas Musala merupakan sarana yang membuat kenyamanan pengunjung agar dapat melaksanakan ibadah pada saat yang tepat. 
Musala yang berada di kawasan wisata Curug Munding sebaiknya direnovasi dan dibuat bangunan yang permanen untuk mempermudah pengunjung dalam melaksanakan ibadah.

\section{- Kebersihan dan Keindahan}

Kebersihan di kawasan wisata Curug Munding harus ditingkatkan, hal tersebut dapat diupayakan dengan banyak cara seperti menambahkan tempat sampah yang layak bagi pengunjung untuk membuang sampah, membentuk petugas kebersihan yang secara teratur merawat kebersihan area wisata.

Kebersihan dan keindahan daerah wisata juga hendaknya menjadi kesadaran wisata bagi masyarakat dan penduduk setempat. Selain itu, wisatawan maupun penduduk dapat menjaga kebersihan jika didukung dengan kondisi dan fasilitas yang memadai. Seperti contohnya, tersedianya tempat sampah. Maka diperlukan banyak tempat pembuangan sampah oleh wisatawan.

Sampah yang dibiarkan begitu saja di daerah wisata, lama kelamaan tidak hanya mengganggu keindahan daerah wisata. Banyak dampak negatif yang ditimbulkan seperti polusi udara berupa bau yang tidak sedap, pemandangan yang terganggu, rusaknya kesuburan tanah, polusi air karena banyaknya sampah hingga masalah kesehatan. Hal-hal itu dapat berdampak buruk pada kesehatan.

\section{- Keamanan}

Faktorkeamanan takkalah penting untuk menjaga keamanan dan kenyamanan bagi pengunjung yang datang. Keamanan sendiri dapat diciptakan dengan cara mengadakan guide atau petugas yang bertujuan untuk menjaga keamanan area wisata.

Menyediakan locker atau lemari bagi pengunjung untuk mengamankan barangbarang milik pengunjung.

\section{- Fasilitas di Area Sekitar Lokasi}

Area sekitar lokasi merupakan suguhan pemandangan yang paling diandalkan, seharusnya diciptakan sedemikian rupa sehingga bisa memuaskan pengunjung. Hal ini bisa diwujudkan dengan menciptakan suasana nyaman dan indah mulai dari masuk jalan setapak yang dihiasi taman dan bungabunga yang indah. Demikian pula tangga dan lokasi area untuk melihat pandangan ke arah air terjun tidak dari tanah, namun akan terasa nyaman bila dibangun dengan benda keras misalnya: batu, paving block, atau beton.

Di lokasi objek wisata akan terasa nyaman bila selalu dalam keadaan bersih, indah, WC dan kamar ganti yang terjaga sanitasinya, tersedianya air bersih dan listrik.

Secara garis besar area sekitar lokasi dibagi ke dalam tiga area, yaitu:

1. Area dalam, yaitu lokasi yang ada di bawah air terjun yang memiliki kedalaman, sehingga perlu dibatasi khusus bagi pengunjung dewasayang bisa berenang.

2. Area dangkal, yaitu kawasan sungai setelah air terjun, merupakan tempat bermain maupu mandi bagi anak-anak maupun orang dewasa.

3. Area pengamatan (view), merupakan lokasi untuk mengamati keindahan air terjun.

\section{- Manajemen dan Kesadaran Wisata}

Stoner (1986) mengartikan manajemen sebagai proses perencanaan, pengorganisasian, memimpindan mengawasi usaha-usaha dari anggota organisasi dan dari sumber-sumber organisasi lainnya untuk mencapai organisasi yang telah ditetapkan. G. R. Terry (1986) - sebagaimana dikutip Malayu S. P Hasibuan (1996) - memandang manajemen sebagai suatu proses, sebagai berikut. 
"Management is a distinct process consisting of planning, organizing, actuating and controlling performed to determine and accomplish stated objectives by the use of human being and other resources".

Sementara, Malayu S. P. Hasibuan (1995) dalam bukunya Manajemen Sumber Daya Manusia mengemukakan bahwa manajemen adalah ilmu dan seni mengatur proses pemanfaatan sumber daya manusia dan sumber-sumber lainnya secara efektif dan efisien untuk mencapai tujuan tertentu.

Suatu organisasi tidak dapat berjalan dengan baik tanpa adanya pengelolaan. Perlu dibentuk organisasi pengelola Curug Munding agar rencana pengembangan Curug Munding menjadi objek wisata yang terkenal dapat berjalan dengan lancar. Selain itu agar tujuan tujuan dari pengembangan Curug Munding dalam aspek ekonomi dan sosial dapat tercapai.

Dalam perencanaan suatu destinasi maupun atraksi keterlibatan masyarakat sangatlah penting seperti dinyatakan oleh Porritti (1998) bahwa masyarakat punya hak dalam perencanaan, demikian pula Timoty (2003) menyatakan bahwa masyarakat lokal lebih tahu apa yang boleh dilakukan dan apa yang tidak sesuai dengan kondisi lokal (dalam Smith dan Robison, 2006). Sesungguhnya masyarakat sekitar objek wisata Curug Munding sangat mendukung apabila dilakukan pengembangan wisata, namun mereka tidak mengerti apa yang harus dilakukan. Oleh karena itu diperlukan upaya untuk menciptakan situasi sadar wisata, yaitu suatu kondisi masyarakat yang dengan kesadaran menciptakan situasi aman, nyaman, bersih dan indah terhadap lingkungannya.

\section{- Promosi}

Pemasaran adalah seluruh kegiatan untuk mempertemukan permintaan dan penawaran, sehingga pembeli mendapat kepuasan dan penjual mendapat keuntungan maksimal dengan risiko serendah-rendahnya (James. J. Spillane dalam Ediwarsyah 1987). Menurut Mursid (2003) Pemasaran adalah semua kegiatan usaha yang bertalian dengan arus penyerahan barang dan jasa-jasa dari produsen ke konsumen. Lebih lanjut Winardi dalam Ediwarsyah (1986) mengatakan bahwa pemasaran adalah aktivitas dunia usaha yang berhubungan dengan arus benda-benda serta jasa-jasa dari produksi sampai konsumsi di mana termasuk tindakan membeli, menjual, menyelenggarakan reklame, menstandarisasi, pemisahan menurut nilai, mengangkut, menyimpan benda-benda, serta informasi pasar.

Suatu daerah wisata dapat berkembang dengan baik dan terkenal jika didukung juga oleh promosi yang baik. Maka itu perlu juga diadakan promosi tentang wisata Curug Munding oleh pemerintah yang berwenang dan oleh pengelola baik melalui media elektronik maupun media cetak.

\section{Merebut Peluang (Opportunities)}

\section{- Destinasi Wisata Alam yang Digemari.}

Masyarakat zaman sekarang pada umumnya sehari-hari bergulat dengan kesibukan pekerjaan, kebisingan, kemacetan dan polusi udara, sehingga hampir setiap orang merindukan situasi alam yang sejuk (green view). Hal ini merupakan peluang yang sangat menjanjikan bagi wisata yang menyuguhkan keindahan alam dengan situasi yang alami, sejuk dan segar. Seperti halnya masyarakat Jakarta yang selalu berbondong berwisata ke Puncak Bogor, sehingga selalu membuat kemacetan terutama pada libur. Alangkah bagusnya apabila mereka tidak semua mengarah ke Puncak Bogor, namun terbagi untuk berwisata ke daerah Lebak Banten, khususnya Wisata Curug Munding. Selama ini mereka tidak memiliki pilihan sehingga keinginan menikmati suasana alam sejuk, hanya didapat dengan wisata ke Puncak Bogor. 


\section{- Dukungan Pemerintah dalam Sektor Pariwisata}

Dalam konsep Nawa Cita khususnya tercantum pada Nawa Cita ke 7 yang berbunyi "Mewujudkan kemandirian ekonomi dengan menggerakkan sektor-sektor strategis ekonomi domestik." Ini merupakan peluang yang bisa digunakan untuk mengembangkan sektor strategis ekonomi khususnya di bidang pariwisata termasuk pengembangan pariwisata Curug Munding.

Di samping itu pemerintah mengupayakan pembangunan di sektor pariwisata dengan membentuk kebijakan tentang industri pariwisata Indonesia yang mengacu pada Undang-Undang (UU RI) No. 10 Tahun 2009 tentang Kepariwisataan, yang mana dalam Undang-Undang ini dibedakan antara usaha pariwisata dan industri pariwisata. Usaha Pariwisata adalah usaha yang menyediakan barang dan/atau jasa bagi pemenuhan kebutuhan wisatawan dan penyelenggaraan pariwisata sedangkan industri pariwisata adalah kumpulan usaha pariwisata yang saling terkait dalam rangka menghasilkan barang dan/atau jasa bagi pemenuhan kebutuhan wisatawan dalam penyelenggaraan pariwisata.

Lebih lanjut dalam Pasal 4 UndangUndang No. 10 Tahun 2009 diuraikan bahwa tujuan pembangunan kepariwisataan adalah:

1. Meningkatkan pertumbuhan ekonomi

2. Meningkatkan kesejahteraan rakyat

3. Menghapus kemiskinan

4. Mengatasi pengangguran

5. Melestarikan alam, lingkungan, dan sumber daya

6. Memajukan kebudayaan

7. Mengangkat citra bangsa

8. Memupuk rasa cinta tanah air

9. Memperkukuh jati diri dan kesatuan bangsa

10. Mempererat persahabatan antarbangsa.

DestinasiwisataCurug Mundingmemiliki potensi daya tarik wisata yang tinggi. Namun, belum berkembang karena keterbatasan infrastruktur yang mendukung minat kunjungan masyarakat. Sejalan dengan Pasal 4 UU No. 10 Tahun 2009 tersebut, diperlukan kerja keras seluruh komponen masyarakat termasuk dalam mewujudkan cita-cita untuk mengembangkan wisata Curug Munding. Ndraha (1987: 110) mengatakan bahwa sesungguhnya peranan pemerintah dalam pembangunan masyarakat amat luas, mulai dari hal yang bersifat pelayanan operasional sampai pada hal-hal yang bersifat ideologi dan spiritual.

Di dalam merencanakan pengembangan pariwisata dikenal beberapa hierarki di mana fokus perencanaan pada tiap tingkat hierarki tidak sama. Perencanaan di tingkat umum memberikan kerangka dan arahan bagi perencanaan hierarki di bawahnya, dan demikian seterusnya (Gunawan, 1993 dalam Paturusi, 2008). Perencanaan tersebut dimulai dari Perencanaan Pariwisata Internasional (PPI), Tingkat Nasional (PPN), Tingkat Wilayah (PPW), tingkat provinsi (PPP) dan tingkat kabupaten/kota (PPK). Khusus untuk perencanaan pariwisata di tingkat kabupaten/ kota (PPK) merupakan arahan kebijakan dan strategi pariwisata wilayah kabupaten/kota dengan fokus pada hal-hal berikut.

1. Kebijakan pengembangan pariwisata kabupaten/kota yang disesuaikan dengan Rencana Pembangunan Jangka Menengah dan Panjang di wilayah kabupaten/kota;

2. Rencana Struktur Tata Ruang Pariwisata kabupaten/kota yang mencakup jaringan transportasi antar dan intra kabupaten/kota sampai ke objek-objek utama;

3. Penentuan kawasan pintu gerbang menuju ke objek utama dan kebutuhan akan fasilitas pendukung (jumlah, jenis, kelas dan lokasi) dan;

4. Rencana jaringan utilitas, pendukung kawasan, dan lokasi objek-objek menarik lainnya. 
Selain itu pemerintah juga memberlakukan Undang-Undang No. 9 Tahun 1990, yang dalam Pasal 1 angka 3 tentang Kepariwisataan jo Pasal 1 angka 3 PP No. 67 Tahun 1996 tentang Penyelenggaraan Kepariwisataan Republik Indonesia kata pariwisata diartikan sebagai segala sesuatu yang berhubungan dengan wisata, termasuk pengusahaan objek dan daya tarik wisata serta usaha-usaha yang terkait di bidang tersebut. Semua kebijakan tersebut merupakan peluang yang sangat baik untuk mengembangkan wisata Curug Munding.

Hal ini diwujudkan dalam bentuk dukungan pemerintah mulai dari perencanaan, pengorganisasian, pelaksanaan dan pengawasan. Perencanaan berupa rencana dukungan fasilitas wisata, organisasi pengelola wisata, pengelolaan wisata dan pengawasan sektor wisata. Menurut Nawawi (1993:6) fungsi pengawasan dapat dilakukan setiap saat, baik selama proses manajemen atau administrasi berlangsung, maupun setelah berakhir, untuk mengetahui tingkat pencapaian tujuan suatu organisasi atau unit kerja. Oleh sebab itu pengawasan sangat penting dilakukan agar bisa mengontrol suatu pekerjaan itu dengan efektif, kalau tidak maka pekerjaan yang diberikan itu tidak akan terealisir sesuai waktu yang ditetapkannya.

\section{- Memiliki Potensi Income yang Tinggi}

Seperti halnya yang termuat dalam Pasal 4 Undang-Undang No. 10 Tahun 2009 menguraikan bahwa tujuan dalam pembangunan kepariwisataan adalah:
a. Meningkatkan pertumbuhan ekonomi
b. Meningkatkan kesejahteraan rakyat
c. Menghapus kemiskinan
d. Mengatasi pengangguran
e. Melestarikan alam, lingkungan, dan sumber daya
f. Memajukan kebudayaan

g. Mengangkat citra bangsa

h. Memupuk rasa cinta tanah air

i. Memperkukuh jati diri dan kesatuan bangsa

j. Mempererat persahabatan antarbangsa.

Undang-Undang No. 9 Tahun 1990 tentang Kepariwisataan menyatakan bahwa pembangunan kepariwisataan sebagai bagian dari pembangunan nasional yang mempunyai tujuan antara lain memperluas dan memeratakan kesempatan berusaha, lapangan kerja dan kesejahteraan rakyat. Dengan demikian pembangunan di bidang kepariwisataan mempunyai tujuan akhir untuk meningkatkan pendapatan masyarakat yang berdampak pada peningkatan kesejahteraan masyarakat.

Peranan pariwisata dalam pembangunan negara secara makro meliputi tiga segi yakni segi ekonomis (sumber devisa, pajak-pajak), segi sosial (penciptaan lapangan kerja), dan segi kebudayaan (memperkenalkan kebudayaan kepada para wisatawan). Ketiga segi tersebut tidak saja berlaku bagi wisatawan asing, tetapi juga untuk wisatawan-wisatawan domestik yang kian meningkat peranannya (Spillane, 1994).

Menurut Poerwadarminta

"Pengembangan adalah suatu proses atau cara menjadikan sesuatu menjadi maju, baik sempurna dan berguna". Yoeti (1996: 53) menegaskan bahwa pengembangan suatu produk pada dasarnya adalah usaha yang dilakukan secara sadar dan berencana untuk memperbaiki produk yang sedang berjalan dan menambah jenis produk yang dihasilkan ataupun yang akan dipasarkan.

Wisata Curug Munding memiliki potensi objek wisata yang tinggi. Hal ini akan membuka kesempatan berusaha bagi masyarakat sekitar untuk melakukan kegiatan dengan menyediakan berbagai macam kebutuhan wisatawan selama berada di Curug Munding. Peluang inilah yang dimanfaatkan oleh masyarakat dengan 
menawarkan berbagai jasa atau barangbarang yang dibutuhkan untuk menarik minat wisatawan yang berkunjung seperti halnya: pemasaran produk hasil bumi, hasil kerajinan tangan, jasa penginapan/ hotel, jasa makanan/oleh-oleh maupun souvenir lainnya. Bertambahnya permintaan kebutuhan jasa dan barang yang dibutuhkan wisatawan, berdampak pada peningkatan pendapatan atau penghasilan masyarakat di kawasan wisata Curug Munding.

Berdasarkan kondisi tersebut, masyarakat setempat perlu mengoptimalkan sumber daya manusia untuk dapat ikut serta dalam kegiatan pariwisata Curug Munding guna meningkatkan pendapatan mereka, karena bagaimana pun kegiatan pariwisata Curug Munding tidak terlepas dari interaksi masyarakat sekitar Curug Munding.

Dengan demikian pasar potensial yang diberikan oleh kawasan wisata bukan semata-mata retribusimasuk kawasan wisata namun berdampak luas kepada ekonomi kerakyatan yang bisa dinikmati oleh seluruh masyarakat, mengatasi pengangguran dan pada akhirnya akan menciptakan ketahanan dan keamanan wilayah.

\section{SIMPULAN}

Dari pembahasan di muka dapat diambil beberapa simpulan antara lain sebagai berikut.

a. Kondisi wisata Curug Munding saat ini.

Saat ini wisata Curug Munding yang memiliki keindahan dan daya tarik wisata masih memiliki kekurangan fasilitas wisata terutama rusaknya jalan masuk ke kawasan wisata, tempat parkir, taman, tangga ke lokasi, listrik, tempat duduk, kamar ganti, WC dan air bersih.

b. Strategi pengembangan kawasan wisata Curug Munding.

Strategi pengembangan Wisata Curug Munding yang paling tepat saat ini adalah menggunakan Strategi "W-O" (weakness-opportunity), yaitu dengan mengatasi kelemahan untuk merebut peluang. Namun pengembangan perlu dilakukan secara terus menerus untuk mendapatkan kawasan wisata yang semakin diminati.

c. Kondisi wisata Curug Munding yang diharapkan.

Terbentuknya kawasan wisata Curug Munding yang siap dipromosikan sebagai wisata unggulan di Kabupaten Lebak, Provinsi Banten. Hal ini bisa terwujud apabila semua kelemahan bisa diatasi, terutama fasilitas wisata khususnya jalan masuk lokasi.

\section{DAFTAR PUSTAKA}

A, Yoeti, Oka. 1996. Pengantar Ilmu Pariwisata, Edisi Revis. Bandung: Angkasa,

Cooper, C. John Fletcher, David Gilbert and Stephen Wanhill. 1993. Tourism: Principles and Practice. London: Pitman Publishing,

Ediwarsyah. 1987. Tesis: Pengaruh Pengembangan Objek Pariwisata terhadap Pendapatan Masyarakat di lingkungan Objek Pariwisata (Suatu Penelitian di kelurahan Parapat Kecamatan Girsang Sipanganbolon Kabupaten Dati II Simalungun Provinsi Dati I Sumatera Utara). Yogyakarta: Fakultas Ilmu Sosial dan Ilmu Politik UGM,

Inskeep, Edward. 1991. Tourism Planning: An Integrated and sustainable Approach. New York: Van Nostrand Reinhold, Inc.

Kaplan, David dan Manner A. A. 2000. Teori Budaya. Yogyakarta: Pustaka Pelajar.

Keraf. 2000. Dimensi Budaya, Ekologi Pesisir dan Laut dalam Pembangunan Wisata Bahari, Naskah Seminar. Denpasar: Kajian Budaya Universitas Udayana.

Lembaga Administrasi Negara Republik Indonesia. Jakarta. 2008. Jakarta: Modul Pendidikan dan Pelatihan Kepemimpinan Tingkat III. 
Marpaung, Happy. 2002. Pengetahuan Kepariwisataan. Bandung: Alfabeta.

Marpaung, Happy dan Herman Bahar. 2002. Pengantar Pariwisata. Bandung: Alfabeta.

Mill, Robert Christie, Alih Bahasa Sastro Tribudi. 2000. Tourism The international Business, Edisi Bahasa Indonesia. Jakarta: PT Raja Grafindo Persada.

Organization. 2003. Sustainable development of Ecotourism: A Compilation of Good Practices in SMEs. Spain

Oka A, Yoeti. 1996. Pemasaran Pariwisata. Bandung: Angkasa.

Pendit Nyoman S. 2002. Ilmu Pariwisata Sebuah Pengantar. Jakarta: Pradnya Paramita.

Paturusi, Syamsul Alam. 2008. Perencanaan Kawasan Pariwisata. Denpasar: Press UNUD.

Poerwadarminta. 1995. Kamus Besar Bahasa Indonesia. Jakarta: Gramedia.
Pitana, Gde I dan Diarta, S. Ketut I. 2009. Pengantar Ilmu Pariwisata. Yogyakarta: C. V. Andi Offset.

Rangkuti, Freddy. 2006. Analisis SWOT, Teknik Membedah Kasus Bisnis. Cetakan Kedua belas. Jakarta: PT Gramedia. Pustaka Utama.

Spillane, J. 1994. Pariwisata Indonesia (Siasat Ekonomi dan Rekayasa Kebudayaan). Yogyakarta: Kanisius.

Stark, Radney. 1987. Sociology. California: Wadsworth Publishing Company Belmont.

Smith, Valene L. 1992. Tourism Alternative. USA: The University of Ttennsylvania Press.

Sugiyono. 2005. Memahami Penelitian Kualitatif. Bandung: CV Alfabeta.

Undang-Undang No. 9 Tahun 1990 tentang Kepariwisataan 